The results show that a significant increase in butterfat production has been obtained when additional copper is fed in the manner described to herds selected at random in the west of Scotland. George Dunlop

West of Scotland Agricultural College, Auchincruive, Ayr. July 14.

1 Dunlop, G., and Wells, H. E., Vet. Rec., 50, 1175 (1938).

${ }^{2}$ Dunlop, G., Nature, 168, 728 (1951).

${ }^{3}$ Cunningham, I. J., N.Z. J. Agric., 69, 559 (1944).

" Dunlop, G., Brit. J. Nutrit., 5, iv (1951).

\title{
Incidence of Meiosis in the Life-cycle of Halidrys siliquosa Lyngb.
}

SEaweeus belonging to the Fucales are diploid, and the reduction division has been shown to occur during the first nuclear divisions in both oogonia and antheridia ${ }^{1-3}$.

$1:$ During a recent investigation of the Fucales on the Northumbrian coast, we have found eight chromosomes in the vegetative cells of plants of Halidrys siliquosa Lyngb. The same number of chromosomes is present at both the first and second divisions in both oogonia and antheridia. This shows that in Halidrys siliquosa meiosis does not take place at the same stage of development as reported for other members of the Fucales. A detailed account of the cytology of this species will be published at a later date.

\section{Eveline ElLiot}

King's College, Betty Moss

Newcastle upon Tyne. August 29.

"Fritsch, "Structure and Reproduction of the Algx", 2, 370 (Cambridg; Univ. Press, 1945).

z Farmer, J. B., and Williams, J. I., Proc. Roy. Soc., 60, 188 (189'). ${ }^{3}$ Yamanouchi, S., Bot. Gaz., 47, 173 (1909).

\section{Embryology of the Emperor Penguin (Aptenodytes forsteri)}

E. A. WILsoN 1 wrote in 1907, "The possibility that we have in the Emperor penguin the nearest approach to a primitive form not only of a penguin but of a bird, makes the future working out of its embryology a matter of the greatest possible importance". With this aim in mind he set out on June 27, 1911, with Bowers and Cherry-Garrard on a terrible journey ${ }^{2}$ in the antarctic winter, during which three embryos were obtained from the Cape Crozier rookery on July 20 . These specimens were described by Parsons ${ }^{3}$, who considered that the smallest one corresponded to a chick embryo of ten days incubation, whereas the two larger specimens corresponded to chick embryos of thirteen days incubation.

It was not until 1949 that Stonehouse ${ }^{4}$ collected a series of Emperor penguin embryos from a rookery fifty miles from one of the bases of the Falkland Islands Dependencies Survey. As a result of this expedition we now possess a new series of sixteen embryos collected between June and August and extending from the primitive streak stage to hatching. All the embryos, with one exception, are in an excellent state of preservation. The poorly preserved specimen was frozen before fixation. The embryos have been

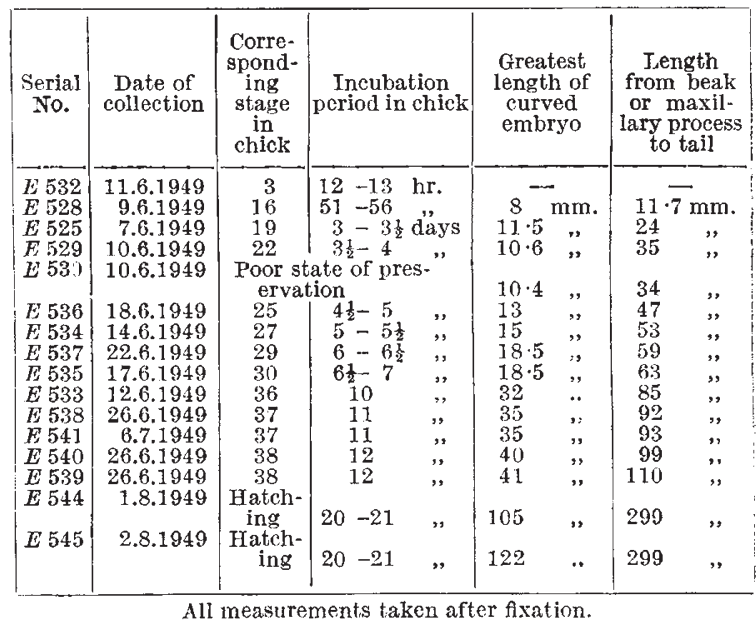

compared with and classified according to the normal stages of development in the chick ${ }^{5}$. The smallest nine specimens which were younger than those brought back by Wilson have been sectioned serially and confirm the observations made by Parsons ${ }^{3}$ on the Gentoo penguin (Pygoscelis papua) and the Ring penguin (Pygoscelis antarctica). However, comparison of the development of the external form of the Emperor penguin with that of the chick and with that of other penguins already described, namely, Gentoo and Ring penguins by Parsons ${ }^{6}$ and Gentoo and Adelie penguins (Pygoscelis adelia) by Waterston and Geddes ${ }^{7}$, reveals a fact not yet recorded and worthy of note. In the earlier embryos the head region is relatively smaller, the neck and tail regions relatively longer, and the curvatures less well marked in penguin than in chick embryos. These features aro more marked in Emperor penguin embryos and result in early penguin embryos resembling early reptilian embryos more closely than do early chick embryos.

It should be pointed out that the embryos collected on June 26 and July 6, 1949, have reached a stage of development similar to that reached by Wilson's largest specimens. 'This observation seems to confirm the ones made by Stonchouse ${ }^{4}$ on measurements of hatched chicks by which he concluded that the chicks of the rookery at Cape Crozier were hatched about three weeks after the ones from the rookery from which the present series was obtained. A detailed description of the embryos is being written for publication in the near future in the Falkland Islands Dependencies Survey Scientific Reports. T. W. GLenister

Department of Anatomy,

Charing Cross Hospital Medical School, 62 Chandos Place,

London, W.C.2.

Jan. 28.

1 Wilson, Edward A., Aves. National Antaretic Expedition, 1901-4, Zoology II, Vertebrata No. 2, 1 (1907).

${ }^{3}$ Cherry-Garrard, Apsley, "The Worst Journey in the World", 2 vols. (London, 1922).

s Parsons, C. W., Penguin Embryos, British Antarctic (Terra Nova) Expedition, 1910, Natural H istory Report, Zoology, 4, No. 7 , Expedition,

4 Stonehouse, Bernard, Nature, 169, 760 (1952). "The Emperor Penguin (Aptenodytes forsteri Gray), 1, Breeding Behaviour and Development". Falkland Islands Dependencies Survey Scientific Reports (in the press, 1953).

s Hamilton, Howard L., Lillie's "Development of the Chick", 3rd edit. (New York, 1952).

"Parsons, C. W., "Discovery" Reports, VI, 139 (Cambridge, 1932).

Waterston, D., and Geddes, A. Campbell, Trans. Roy. Soc. Edin. 47, $223(1909)$. 